\title{
Dynamic Seismic and Wind Response of Masonry Minarets
}

\author{
Erdem Türkeli ${ }^{*}$ \\ ${ }^{1}$ Vocational School of Technical Sciences, Construction Department, Ordu University, Cumhuriyet District, Mustafa Kemal Blv. \\ 478, 52200, Ordu, Turkey \\ * Corresponding author, e-mail: erdemturkeli@odu.edu.tr
}

Received: 30 September 2019, Accepted: 30 January 2020, Published online: 09 March 2020

\begin{abstract}
Historical masonry structures i.e. minarets, towers, mosques or bastions are the heritage of past generations to the future societies as they carry the traces of the past communities. Among these structures, historical masonry minarets are one of the most generally constructed structure that reflects the beauty and magnificence of Islamic culture. Under severe winds and earthquakes, most of them were severely damaged or collapsed. Therefore, it is an inevitable duty for us to conduct and investigate their dynamic behavior under these vital actions of nature. In this study, the dynamic seismic and wind response of a historical minaret of i̇skenderpaşa Mosque that is selected from the technical literature is investigated by using different methods i.e. wind loading procedures of TS498, CICIND Model Code and Eurocode 1, the design spectrums of CICIND Model Code and Eurocode 8 for different types of soils, the time histories of real ground motions of Düzce and Kocaeli Earthquakes. At the end of the study, top joint displacements and stress distributions are obtained and interpreted. The findings of this study showed that the dynamic behavior of this historical masonry minaret is wind dominant (CICIND Model Code) and tensile and shear stress accumulations at the junction point of transition segment and cylindrical body of the minaret is the main reason for the collapse without showing any ductile behavior.
\end{abstract}

Keywords

masonry, minaret, wind, seismic, earthquake, response, dynamic

\section{Introduction}

From ancient times, minarets were used for announcing azan to the people having the aim of pray. However, as time passes, this mission of minarets diminished and they were utilized for completing the magnificence and beauty of mosques. Also, in time, the height of these slender structures increased that makes them more vulnerable to severe winds and earthquakes. Due to this reason, the design of these special structures also require intensive care that is determining the loads acting to the load carrying systems of these structures is very crucial. Winds and earthquakes can be counted as the most dominant actions of nature that enforces the load carrying capacity of these structures. Reinforced concrete (RC) or masonry minarets, RC chimneys, steel stadium lighting towers, RC silos or steel turbine towers etc. can be categorized as tall and slender structures [1-4].

Masonry minarets can be counted as one of the most constructed slender structure in Turkey. Also, their value in architectural heritage is very high as they carry the traces of past civilizations to the future generations. From this point of view, understanding the seismic and wind behavior of these structures is of great importance.
Turkey is an active tectonic region that severe earthquakes frequently occur. Earthquake hazard map (Fig. 1) is updated by Disaster and Emergency Management Presidency in 2018 and provided for the use of open to the public. By utilizing this map [5], the peak ground accelerations of the individual locations can be obtained.

It is clearly identified from the red zones of Fig. 1 that active tectonic behavior is frequently observed. These motions of the land causes earthquakes that have magnitudes greater than $7.0 \mathrm{M}_{\mathrm{w}}$.

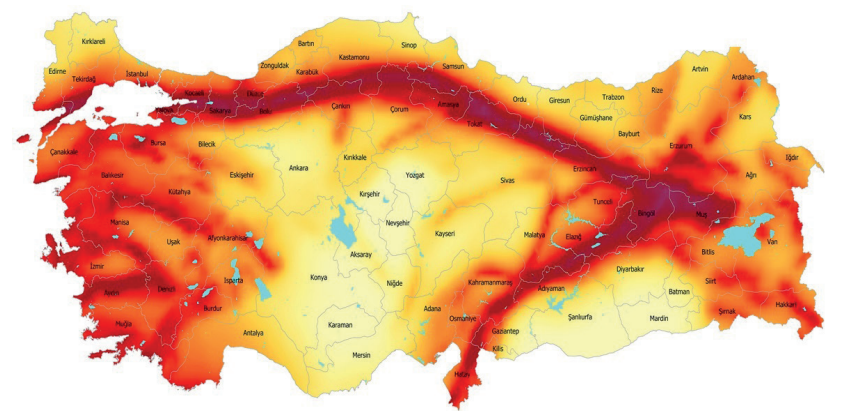

Fig. 1 Earthquake hazard map of Turkey [5] 
Also, from the year of 1900 up to this time, some of the destructive earthquakes occurred in Turkey are provided in Table $1[6,7]$.

It is clear from Table 1 that earthquakes that have magnitudes $\left(\mathrm{M}_{\mathrm{w}}\right)$ higher than 5.0 frequently occurred causing loss of lives and economy. Also, the wind map of Turkey is provided in Fig. 2 [8].

From Fig. 2, it can be clearly seen that the coastal regions have the potential to face with severe wind storms. Also, three sides of Turkey are surrounded by sea that increases the tendency of this phenomenon.

In recent earthquakes and wind storms, there are so many masonry minarets structurally suffered. Wind storms or severe seismic actions are the main reasons for totally or partially damage occurred on masonry minarets. Some of these catastrophic events are provided below.

The masonry minaret of the Kurtuluş Mosque (Fig. 3), a 22-year-old town in the Bahçelievler neighborhood of Kırıkkale (Turkey), was destroyed by strong winds [9].

Table 1 Destructive earthquakes occurred in Turkey [6, 7]

\begin{tabular}{lcc}
\hline Earthquake & Year & Magnitude $\left(\mathrm{M}_{\mathrm{w}}\right)$ \\
\hline Marmara Sea & 26 September 2019 & 5.8 \\
Van & 23 October 2011 & 7.2 \\
Doğubeyazit & 2 July 2004 & 5.0 \\
Bingöl & 1 May 03 & 6.4 \\
Pülümür & 27 January 2003 & 6.0 \\
Sultandağ1 & 03 February 2002 & 6.3 \\
Çankir1 & 6 June 2000 & 5.9 \\
Düzce & 12 November 1999 & 7.2 \\
Kocaeli & 17 August 1999 & 7.4 \\
Dinar & 1 October 1995 & 6.1 \\
Erzurum & 30 October 1983 & 6.8 \\
Gediz & 28 March 1970 & 7.2 \\
Mudurnu & 1967 & 7.1 \\
Bolu-Gerede & 1944 & 7.2 \\
Erzincan & 1939 & 7.9 \\
\hline
\end{tabular}

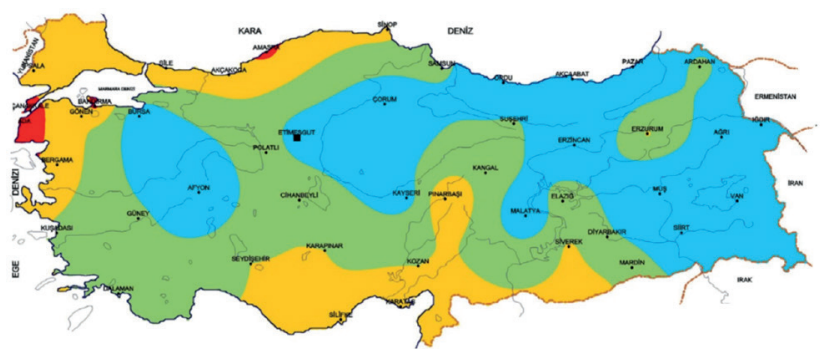

Fig. 2 Wind map of Turkey [8]
The 57-meter-long masonry minaret of the central mosque in the neighborhood of Koşaca in the district of Ulubey (Turkey) (Fig. 4), which is known as the mosque with the longest minaret in the province, was destroyed due to the strong winds in Ordu [10].

Also, the masonry minaret of the Defterdar İbrahim Efendi Mosque on Kos Island (Fig. 5) was destroyed during the earthquake in the Aegean Sea [11].

In the destructive earthquake that took place in Erciş district of Van (Turkey) Province on 23 October 2011, heavy damage occurred in the second minaret (Fig. 6) of the Central Kara Yusuf Paşa Mosque [12].

Masonry minarets have the ability to carry the traces of the history and past communities to the next generations. Also, they can be categorized as one of the most generally constructed tall and slender type of structure in Turkey and in some countries in the world. All over world, so many masonry minarets were constructed and construction of many of them are ongoing. Therefore, it is very crucial to determine the loads acting to these special structures. From the detailed search of the technical literature,

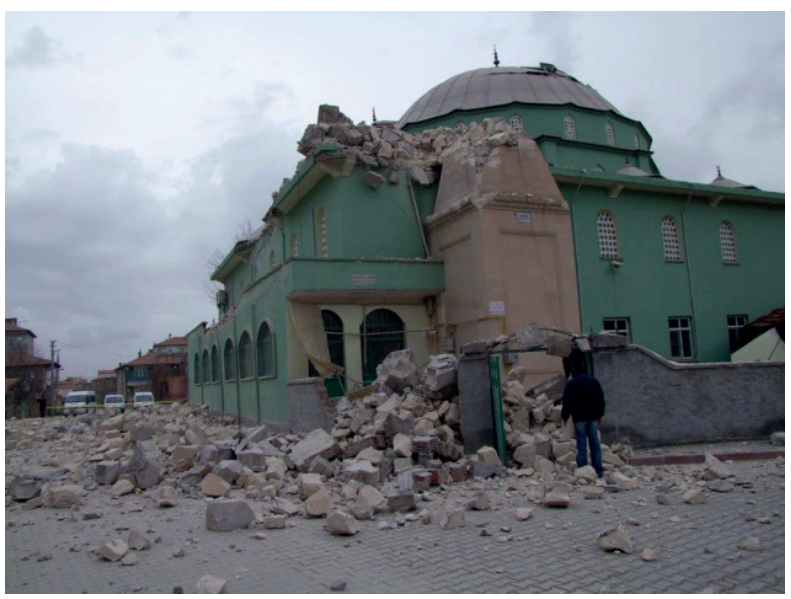

Fig. 3 Demolished minaret of Kurtuluş Mosque [9]

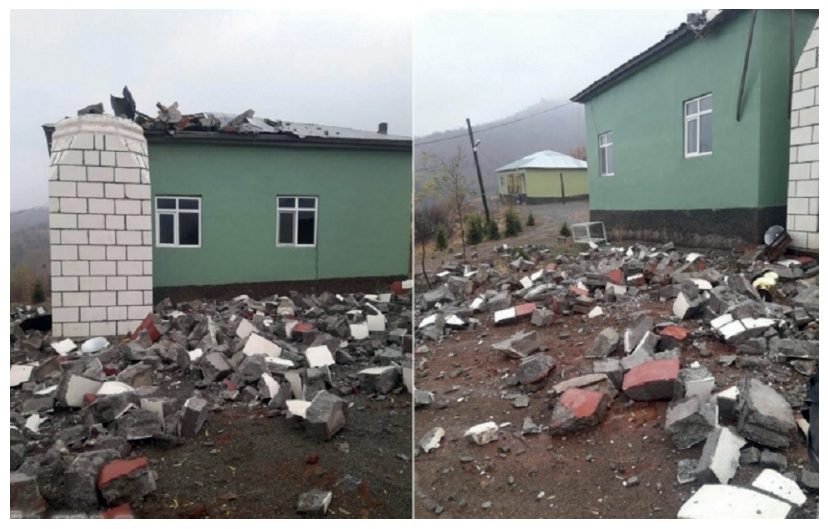

Fig. 4 Demolished minaret located in Ulubey [10] 


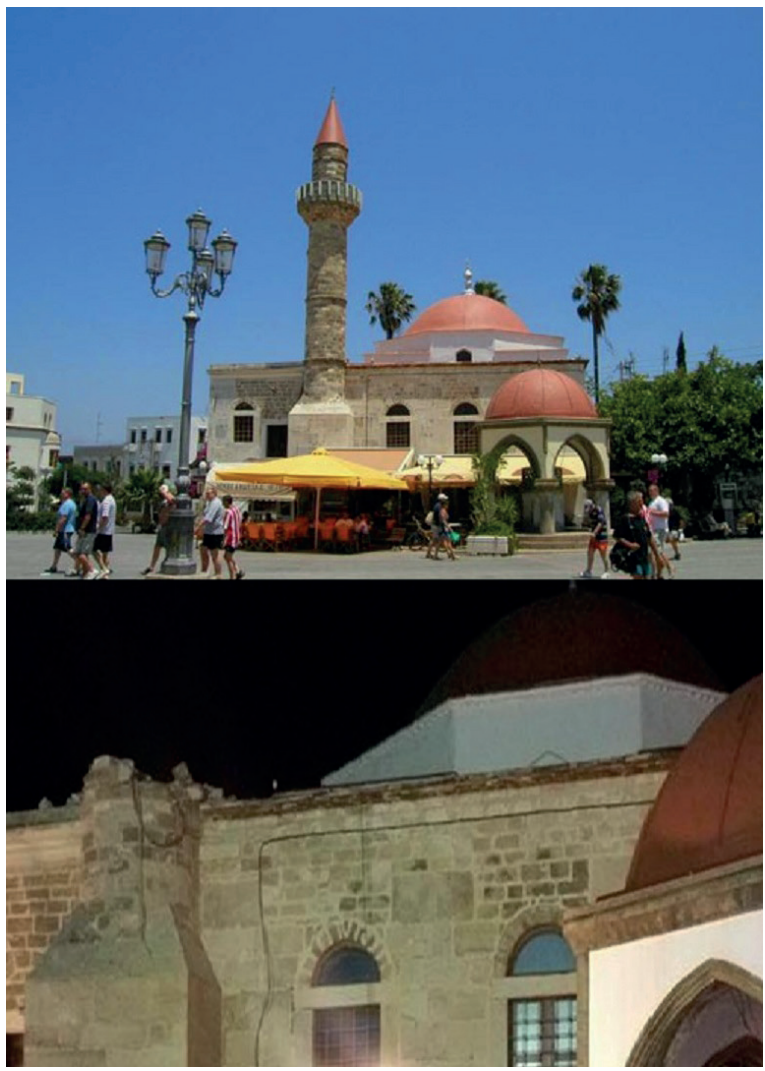

Fig. 5 Demolished minaret located in Kos Island [11]

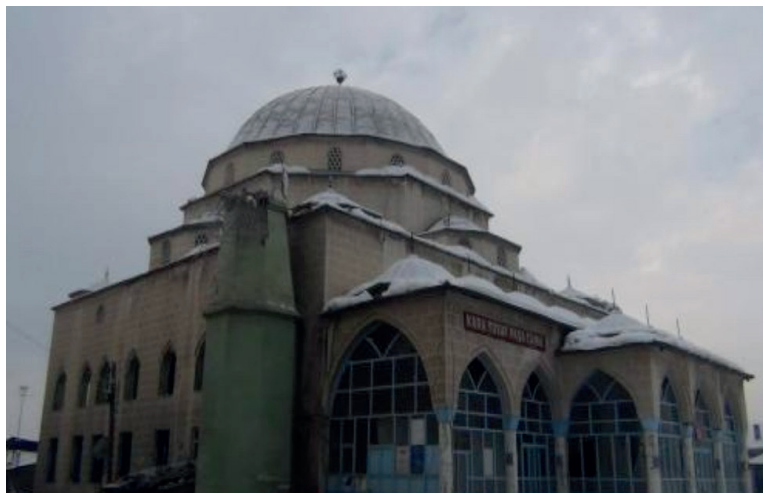

Fig. 6 Heavy damage on minaret located in Van [12]

up to this present study, it can be clearly identified that there is no study that deals with both wind and earthquake response of masonry minarets. In this point of view, the novelty of this study for the technical literature is the comparison of the wind and seismic response of masonry minarets by utilizing different analyses methods. By this way, the dominant behavior type of the minaret can be identified. Also, the catastrophic events dealt in the introduction part of the study compel researchers to conduct such research studies to identify the weak points of the structural systems of these special structures. In this manner, this study can be considered as a benchmark study.
In technical literature, some of the researchers only dealt with the seismic response of masonry minarets [13-41]. However, as in the case of this study, wind loading can become the dominant load. Therefore, the effect of both the wind and seismic loading should be analyzed and considered in the structural analysis and design.

In this present study, wind and seismic loading is considered for the dynamic analyses. In order to do that alongwind and across-wind forces provided in different codes were analyzed separately. Also, in the seismic loading analysis, design spectrums according to different codes were utilized along with time history analyses of real destructive earthquakes.

The remainder of this article is classified in six sections, as follows. Section 2 is devoted to the description of the methodology and brief information about the methods utilized in the structural analyses. In Section 3, historical information about the İskenderpaşa historical minaret and verification of the finite element model is provided. Section 4 presents the wind loads calculated according to TS498, CICIND Model Code and Eurocode 1. In Section 5, the analyses results obtained from different analyses techniques are presented. A discussion part is following Section 5 that the analyses results are interpreted and compared with each other. Finally, some concluding remarks are provided in Section 7.

\section{Methodology}

In this part of the study, the basic ideas lying behind the analysis concepts and brief information about the procedures of the methods utilized in this study are provided.

Wind loading can be classified into two categories namely along-wind and across-wind. Along-wind loads are the ones that are in the parallel direction with the direction of the wind. However, across-wind forces have the direction perpendicular to that of wind. In some standards, only the procedures of along-wind loading is provided and the across-wind loading is neglected. Although this may be the case for many of the civil engineering structures, this approach is not valid for tall and slender structures like masonry minarets. Therefore, in this study, CICIND Model Code wind loading procedure that deals with across-wind loading is utilized with TS498 and Eurocode 1 that are not dealing with across-wind loading. In this point of view, this study is representing a comparison between these two approaches. Also, CICIND Model Code and Eurocode 1 includes the parameters about the dynamic properties i.e. the first mode frequency of the 
masonry minaret. Therefore, these procedures can be considered as dynamic wind loadings among other wind loading procedure i.e. TS498. This study is also representing a comparison between static and dynamic wind loadings. In this study, all of these wind loadings were applied statically to the considered masonry minaret.

In the seismic analysis of this study, linear static and dynamic analyses are considered. Linear static analyses are performed by using the response spectrum method, which is a function of frequency or period, showing the peak response of a simple harmonic oscillator subjected to a transient event i.e. earthquake. The design response spectrum can be seen as an envelope over all known and anticipated earthquakes in a certain geographical region [42]. In this study, the design spectrums of the internationally accepted standards i.e. CICIND Model Code and Eurocode 1 are utilized. In these analyses, the response spectrums are constructed according to the structural parameters of the considered masonry minaret and applied to the minaret. Also, to determine the natural frequencies and mode shapes in the analytical modal, the free vibration equation of motion below is utilized.

$[M]\{\ddot{X}(t)\}+[K]\{X(t)\}=0$,

where $[M]$ and $[K]$ represent the mass and rigidity matrices and $\ddot{X}(t)$ and $X(t)$ are vectors of time varying acceleration and displacement, respectively [31].

Finally, in the linear time history analyses utilized in this study, linear elastic force-deformation relationships are considered. This is valid for the structural analyses of the considered minaret because it is not possible to determine the exact nonlinear behavior of the material due to reason provided by Altunisik [16] that removing test samples from the historical masonry structures such as minarets was not allowed by the related institution. Therefore, in this study, nonlinear analyses can't be performed for the structural analyses of the considered minaret.

Only brief knowledge about the procedures of the codes utilized in the structural analyses is provided as they are open to the use of the public.

\subsection{TS 498}

The total resultant wind load $(W)$ given in Eq. (2) is the combination of aerodynamic load parameter $\left(C_{f}\right)$, suction $(q)$ (wind pressure) and surface area $(A)$ affected.

$W=C_{f} \cdot q \cdot A$
In this standard [43] aerodynamic load parameters for different type of structures are provided in a table. Also, from this table, the relevant information regarding towertype structures can be selected. In the standard, there is no equation provided to consider across-wind forces.

\subsection{CICIND Model Code}

Along-wind and across-wind (vortex shedding phenomena) components of wind forces should be calculated for these types of slender and vertical structures whose aspect ratios (i.e. ratio of height to width of the structure) are high. Total along-wind load on unit height is the combination of mean wind load and wind load according to instantaneous wind effect given in Eqs. (3)-(4), respectively.

$$
\begin{aligned}
& w_{m}(z)=0.5 \cdot \rho_{a} \cdot[V(z)]^{2} \cdot C_{D} \cdot d(z) \\
& w_{g}(z)=\frac{3 \cdot(G-1)}{h^{2}} \cdot \frac{z}{h} \cdot \int_{0}^{h} w_{m}(z) \cdot z \cdot d z
\end{aligned}
$$

In Eqs. (3)-(4), the explanation of symbols used in the along-wind force calculation procedure is given comprehensively as follows: $z$; height of structure from ground, $w_{m}(z)$; mean wind load on unit height, $w_{g}(z)$; equivalent static wind load calculated according to instantaneous wind effect on unit height, $\rho_{a}$; air density $\left(1.25 \mathrm{~kg} / \mathrm{m}^{3}\right)$, $C_{D}$; shape parameter, $d(z)$; the outer diameter of minaret at height $z, h$; height of structure from ground, $G$; instantaneous wind parameter.

In the standard [44], it is stated that if the equation given in Eq. (5) is satisfied for all sections considered, there is no need to analyze the across-wind forces (formed from vortex separated from the across-wind surface of minaret).

$\frac{G}{V} \geq 2.0 \mathrm{kN} / \mathrm{m}^{3}$

In Eq. (5), $G$ and $V$ are denoting the weight of the tower above the section that is considered and the volume of the tower for the height that the section considered, respectively. Also, it is stated in CICIND Model Code [44] that if Eq. (5) is not satisfied for the sections considered, then the procedures given in ACI 307/98 "Design and Construction of Reinforced Concrete Chimneys" [45] should be used for the calculation of across-wind forces. In ACI 307/98, the peak base moment due to across-wind forces, $M_{\text {emax }}$ can be calculated from Eq. (6)

$$
M_{\text {emax }}=G \cdot S_{S} \cdot c_{L} \cdot \frac{\rho_{a}}{2} \cdot V_{c r}^{2} \cdot d(u) \cdot h^{2} \cdot\left[\frac{\pi}{4 \cdot\left(\beta_{s}+\beta_{a}\right)}\right]^{\frac{1}{2}} \cdot S_{p} \cdot\left[\frac{2 \cdot L}{\frac{h}{d(u)}+c_{E}}\right]^{\frac{1}{2}}(6)
$$


In Eq. (6), $d(u)$ is denoting average outer diameter of upper $1 / 3$ part of the minaret, $G$ is maximum multiplier (taken as 4.0), $g$ is gravitational acceleration (taken as $9.81 \mathrm{~m} / \mathrm{s}^{2}$ ), $S_{s}$, mode shape factor (taken as 0.57 for $1^{\text {st }}$ mode), $C_{L}$ is uplifting force parameter, $\rho_{a}$ is air density $\left(1.25 \mathrm{~kg} / \mathrm{m}^{3}\right), L$ is correlation length factor (taken as 1.20 ), $C_{E}$ is end factor (taken as 3.0), $h$ is total height of the minaret, $V_{c r}$ is critical wind speed at of the minaret, $\beta_{a}$ is aerodynamic damping, $\beta_{s}$ is critical damping quantity, $S_{p}$ is spectral parameter.

Across-wind actions should be combined with the alongwind actions occurring at the same time by using Eq. (7);

$M_{w}(z)=\left\{\left[M_{\text {emax }}(z)\right]^{2}+\left[M_{1}(z)\right]^{2}\right\}^{\frac{1}{2}}$.

In Eq. (7), $M_{\text {emax }}$ is denoting maximum base moment due to across-wind forces given with Eq. (6) and $M_{1}(z)$ is denoting the moment occurred due to average along-wind actions.

\subsection{Eurocode 1}

Total wind load is shown in Eq. (8).

$$
F_{w}=c_{s} c_{d} \cdot c_{f} \cdot q_{p}\left(z_{e}\right) \cdot A_{r e f}
$$

In Eq. (8), $c_{s} c_{d}, c_{f}, q_{p}\left(z_{e}\right)$ and $A_{r e f}$ are denoting the structural factor, the force coefficient, peak velocity pressure and the reference area for the structure, respectively. This standard [46] deals with buildings and civil engineering works with heights up to $200 \mathrm{~m}$.

\subsection{Design spectrum (CICIND Model Code)}

The ordinate of the elastic response spectrum $a_{s}(T)$ is given with Eq. (9), Eq. (10) and Eq. (11).

$$
\begin{aligned}
& a_{s}(T)=a \cdot(1+20 \cdot T) \quad T \leq 0.1 s \\
& a_{s}(T)=3 a \quad 0.1 s<T \leq 0.4 s \\
& a_{s}(T)=3 \cdot a \cdot S \cdot\left(\frac{T}{0.4}\right)^{\beta} \leq 3 a \quad 0.4 s<T
\end{aligned}
$$

In these equations, $T$ is denoting the period of structure, $\mathrm{a}$ is denoting the maximum ground acceleration where tower is located, $S$ is soil factor depending of soil type and $\beta$ is denoting a soil dependent factor. For different types of soil, $S$ and $\beta$ factors are shown in Table 2.

Moreover, for the purposes of this study, maximum ground acceleration factor is determined as 0.4. By using 0.01 second time interval steps, the dimensionless calculated and drawn design response spectrum for different types of soils is shown in Fig. 7.
Table 2 Factors dependent on soil type for CICIND Model Code [44]

\begin{tabular}{lcc}
\hline Soil Type & $S$ Factor & $\beta$ Factor \\
\hline S1 & 1.00 & -0.80 \\
S2 & 1.20 & -0.67 \\
S3 & 1.50 & -0.67 \\
\hline
\end{tabular}

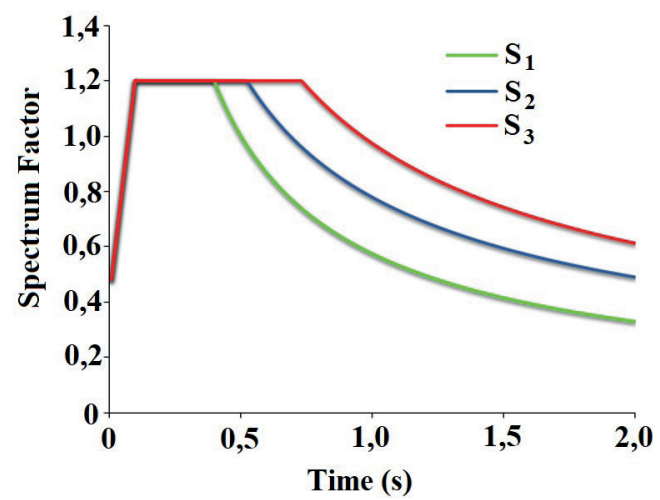

Fig. 7 The design response spectrum curves for different soil types according to CICIND Model Code

\subsection{Design spectrum (Eurocode 8)}

The ordinate of the elastic response spectrum $S_{d}(T)$ is given with Eq. (12), Eq. (13) and Eq. (14).

$$
\begin{aligned}
& S_{d}(T)=\alpha \cdot S \cdot\left[1+\frac{T}{T_{B}} \cdot\left(\frac{\beta_{0}}{R}-1\right)\right] \quad 0 \leq T \leq T_{B} \\
& S_{d}(T)=\alpha \cdot S \cdot \frac{\beta_{0}}{R} \quad T_{B} \leq T \leq T_{C} \\
& S_{d}(T)=\alpha \cdot S \cdot \frac{\beta_{0}}{R}\left[\frac{T_{c}}{T}\right] k_{d l} \geq 0.20 \cdot \alpha \quad T_{C} \leq T \leq T_{D}
\end{aligned}
$$

In these equations, $S_{d}(T)$ is the elastic response spectrum; $T$ is the vibration period of a linear single-degree-of-freedom system; $\alpha$ is the design ground acceleration; $T_{B}$ is the lower limit of the period of the constant spectral acceleration branch; $T_{C}$ is the upper limit of the period of the constant spectral acceleration branch; $T_{D}$ is the value defining the beginning of the constant displacement response range of the spectrum; $S$ is the soil factor; $\beta_{0}$ is spectral magnification coefficient; $R$ is behavior factor and $k_{d 1}$ is a factor dependent on soil type. For different types of soil, the factors utilized in Eqs. (12)-(14) are provided in Table 3 [47].

Table 3 Factors dependent on soil type for Eurocode 8 [47]

\begin{tabular}{lcccccc}
\hline Soil Type & $S$ Factor & $\beta_{0}$ Factor & $T_{B}(\mathrm{~s})$ & $T_{C}(\mathrm{~s})$ & $T_{D}(\mathrm{~s})$ & $k_{d 1}$ Factor \\
\hline $\mathrm{A}$ & 1.00 & 2.50 & 0.10 & 0.40 & 3.0 & $2 / 3$ \\
$\mathrm{~B}$ & 1.00 & 2.50 & 0.15 & 0.60 & 3.0 & $2 / 3$ \\
$\mathrm{C}$ & 0.90 & 2.50 & 0.20 & 0.80 & 3.0 & $2 / 3$ \\
\hline
\end{tabular}




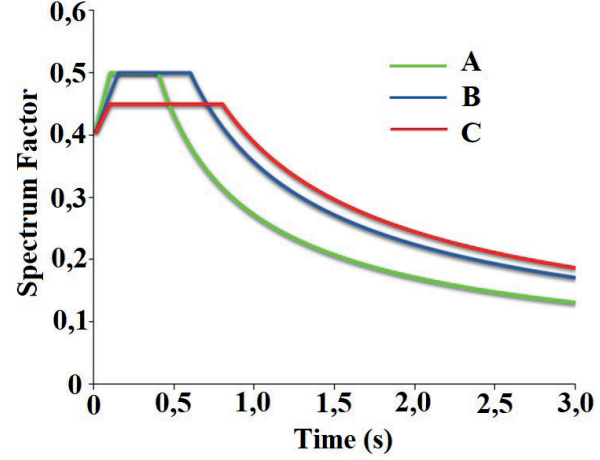

Fig. 8 The design response spectrum curves for different soil types according to Eurocode 8

Moreover, for the purposes of this study, maximum ground acceleration factor is determined as 0.4. The behavior factor, $R$, is selected as 2.00 . By using $0.01 \mathrm{sec}-$ ond time interval steps, the dimensionless calculated and drawn design response spectrum for different types of soils is shown in Fig. 8.

\subsection{Time history analysis of real ground motions}

Two recorded ground motions of 17 August 1999 Kocaeli and 12 November 1999 Düzce Earthquakes are applied to the cited masonry minaret in the linear dynamic modal time history analyses. These cited ground motions were simulated and applied with $0.005 \mathrm{~s}$ time intervals. The number of applied steps of these earthquakes are 12.000 and 5.182 for 17 August 1999 Kocaeli and 12 November 1999 Düzce earthquakes, respectively [7]. These ground motions are illustrated in Figs. 9-10.

\section{Iskender Pasha historical minaret and calibrated finite element model (FEM)}

In this study, the historical minaret (Fig. 11) of İskenderpaşa Mosque located in Trabzon district of Turkey is selected as the case study.

Iskender Pasha, who was one of the governors of Trabzon of the Kanuni era, made important contributions to the city's development. Also, the Iskender Pasha historical minaret was built by the governor of Trabzon (Iskender Pasha) in the XVI century. The minaret was made in alternate style with bricks and colored stones with beautiful decorations under the balcony. Scarecrows are decorated with emblems and circular motifs $[16,49]$.

It is a fact that finite element modelling (FEM) method is the most generally conducted method in the dynamic analysis of civil engineering structures. However, the FEM of the structures should be calibrated or updated before using in the dynamic analyses.

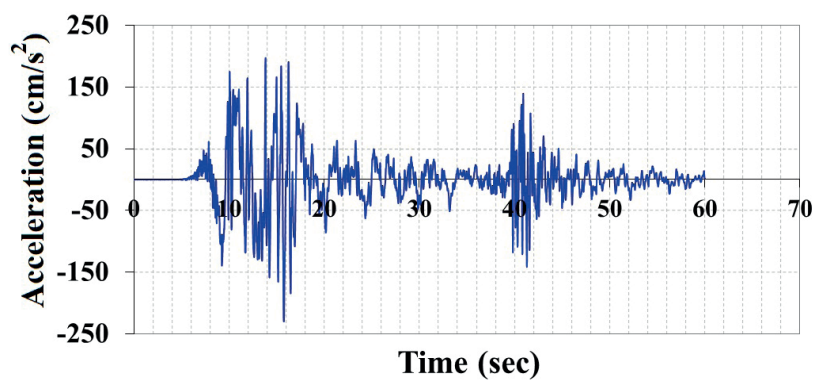

Fig. 9 Ground motions recorded at YPT station during 17 August Kocaeli earthquake

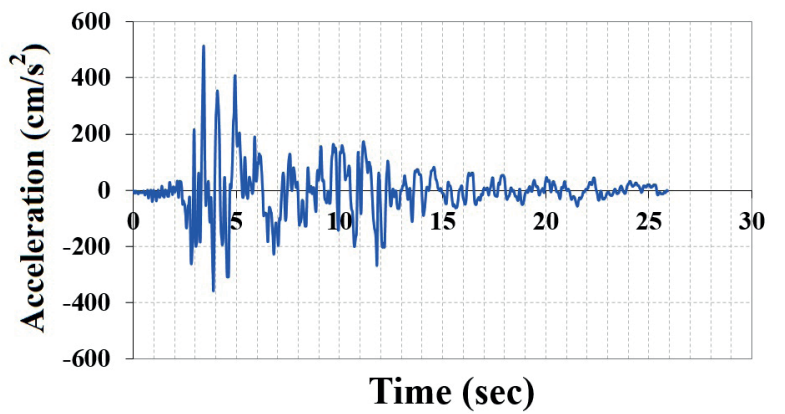

Fig. 10 Ground motions recorded at DZC station during 12 November Duzce earthquake

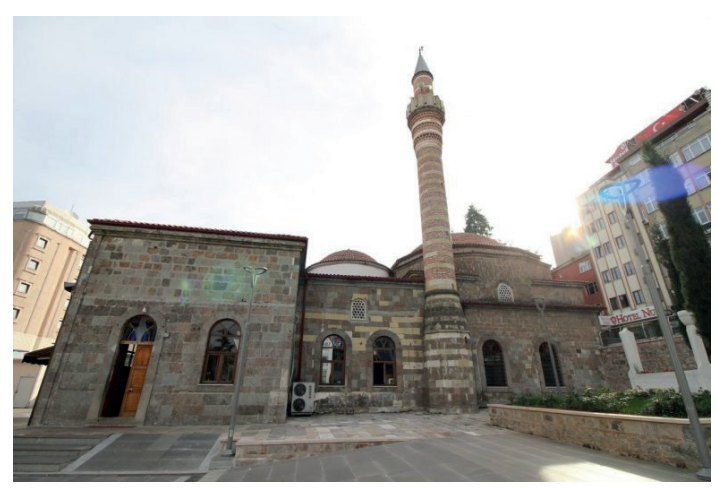

Fig. 11 Historical minaret of Iskender Pasha Mosque [48]

There are some ways to calibrate, update or verify the FEM models of the civil engineering structures. One of the most utilized recent technique is the "Operational Modal Analysis" technique [41, 50, 51]. Although this technique provides almost accurate results, special instrumentation is needed to obtain the dynamic characteristics of the structure. Sometimes, it is a difficult task to place the accelerometers to the tall and slender structures like minarets or RC chimneys etc. Also, the sensitivity of the measurements, the number of accelerometers, environmental effects can be effective in obtaining the dynamic results. Another method is the use of the calibrated model that is provided in the technical literature. By this way, only the comparison of mode frequencies and mode shapes of the FEM model with the calibrated one is enough. If there is 
no significant difference $(<5 \%)$ in these dynamic characteristic comparisons, the produced FEM model can be utilized safely in the dynamic analyses.

In this study, the considered historical masonry minaret, İskenderpaşa historical minaret, is selected from technical literature as the dynamic characteristics of this minaret is obtained and verified both analytically and experimentally by Altunişik [16]. Therefore, it is only needed to compare the dynamic characteristics of the FEM model produced in this study with the ones obtained by Altunişik [16]. In order to do that several iterations were performed on the produced FEM model to closely approximate the dynamic characteristics of Altunişik [16]. At the end of these iterations, the closest FEM model that represents the dynamic characteristics of the validated model by Altunişik [16] is decided to be used in dynamic analyses. In Table 4, the percentage error comparisons of unverified and verified models with the ones obtained from Altunişik [16] are provided.

It is clear from Table 4 that the errors decreased to acceptable ratios (less than $5 \%$ ) as the calibration of the model is performed according to the results obtained from Altunişik [16]. Also, the first five mode shapes of the verified FEM model according to the ones obtained from Altunişik [16] are given in Fig. 12 to verify the FEM.

From Fig. 12, it can be clearly identified that the mode shapes of the produced model are in accordance with the ones obtained from Altunişik [16]. Therefore, this produced model can be accurately utilized in the dynamic analyses. In this study, SAP2000 structural analysis program [52] is utilized in producing the FEM model of İskenderpaşa historical minaret that this program is capable of conducting linear and non-linear dynamic analyses of civil engineering structures. As this structure is a historical masonry minaret, only solid elements (Fig. 13) are considered in the production process [53].

Solids are eight-node objects used to model 3D structural systems. Each solid has six quadrilateral faces with a joint at each corner. Nodes may be collapsed to form

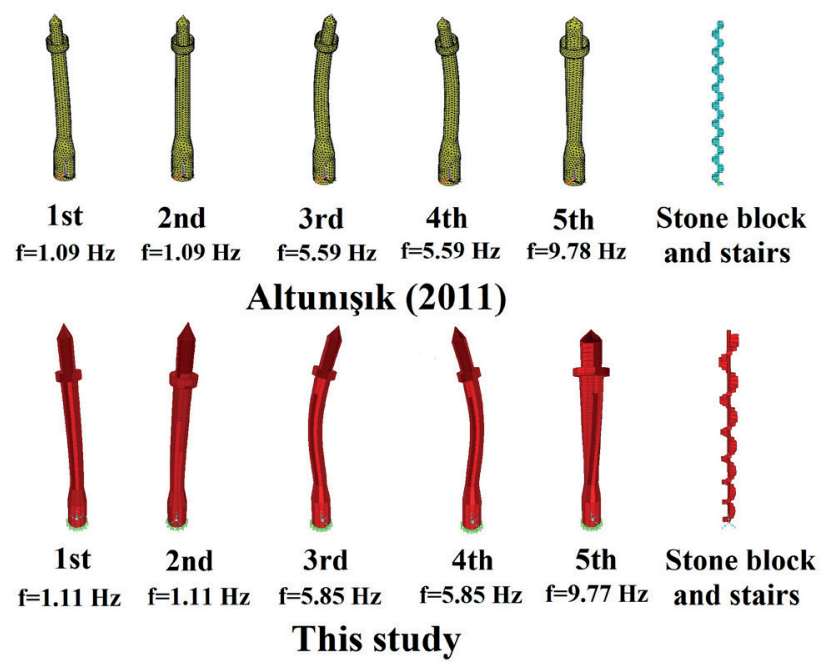

Fig. 12 Verification of the mode shapes of the model

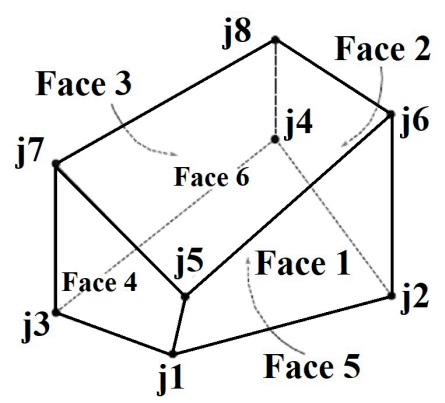

Fig. 13 Properties of solid element [53]

wedges, tetrahedra, and other irregular volumes. Material, temperature-dependent, and anisotropic properties may be assigned, and gravity loads, surface pressures, pore pressures, and thermal loads may be applied. Aspect ratios should be less than four, while those near unity provide for the best results [53].

As in the original study conducted by Altunisik [16], the soil structure interaction and the mosque structure besides the considered historical minaret is not considered in the dynamic analyses. Also, the nodes at the bottom part of the minaret is considered as fixed (Fig. 12). Other than the base of the minaret, there is no other lateral or vertical restraint on the structure. Moreover, only the material self-weights (no other gravity loads are acting) are taken into account in

Table 4 Validation of the FEM model utilized in this study

\begin{tabular}{|c|c|c|c|c|c|c|}
\hline Mode Number & $\begin{array}{c}\text { Modal Frequency } \\
\text { (Hz.) (Altunisik) [16] }\end{array}$ & $\begin{array}{c}\text { Unverified Model Modal } \\
\text { Frequency (Hz.) (This study) }\end{array}$ & $\begin{array}{l}\text { Error } \\
(\%)\end{array}$ & $\begin{array}{l}\text { Updated FEM Model Modal } \\
\text { Frequency (Hz.) (This study) }\end{array}$ & $\begin{array}{c}\text { Error } \\
(\%)\end{array}$ & $<5 \%$ \\
\hline 1 & 1.09 & 1.19 & 9.17 & 1.11 & 1.83 & $\checkmark$ \\
\hline 2 & 1.09 & 1.19 & 9.17 & 1.11 & 1.83 & $\checkmark$ \\
\hline 3 & 5.59 & 6.58 & 17.71 & 5.85 & 4.65 & $\checkmark$ \\
\hline 4 & 5.59 & 6.58 & 17.78 & 5.85 & 4.65 & $\checkmark$ \\
\hline 5 & 9.78 & 10.91 & 11.55 & 9.77 & 0.10 & $\checkmark$ \\
\hline
\end{tabular}


the initial stage of analyses. Apart from the original study conducted by Altunisik [16], in this study, wind loading in along-wind and across-wind directions according to important codes are considered. Also, different from the original study, the seismic loads induced by design spectrums for different soil conditions are taken into account. Moreover, two time histories of the recorded real earthquakes are applied. From this point of view, this study provides a comprehensive standpoint to the dynamic seismic and wind analyses of masonry minarets. The material properties of the masonry stone are also obtained from Altunisik [16] that modulus of elasticity, Poisson's ratio and mass per unit volume are $2.0 \times 109 \mathrm{~N} / \mathrm{m}^{2}, 0.2$ and $2169 \mathrm{~kg} / \mathrm{m}^{3}$, respectively.

The geometrical properties of the historical minaret of İskenderpaşa Mosque in accordance with Altunisik [16] are provided in Fig. 14.

The presence of a nearby structure influences the pressures on a high-rise building due to interference [54]. Therefore, as in the original study conducted by Altunisik [16], the dynamic behavior of the modeled masonry minaret is evaluated considering that there are no structures near or around that means the interference effect is not in the scope of this study. In another words, the effect of the mosque and other structures besides the İskenderpaşa historical minaret is neglected while determining the wind and earthquake behavior of the cited minaret.

\section{Calculation of wind loads}

In this part of the study, as indicated before, TS498, CICIND Model Code and Eurocode 1 is utilized for the calculation of wind loads acting on the minaret. Unfortunately, there is no specific structural wind and earthquake design standard for these types of masonry minarets. Therefore, these cited standards can be used to calculate wind loads. For these

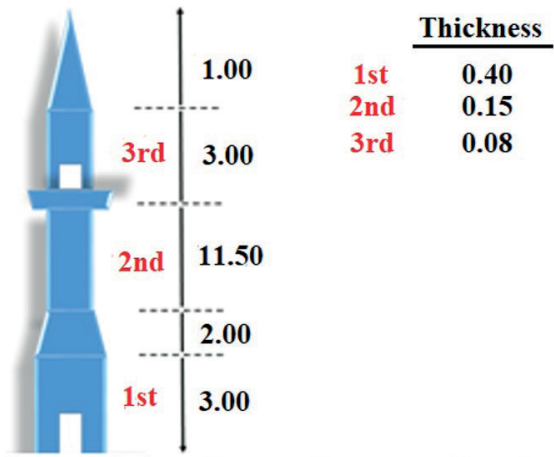

Note: All dimensions are in meters. Drawings are not in scale. Section numbers are given in red.

Fig. 14 Geometric characteristics of historical minaret of İskenderpaşa Mosque types of slender masonry minarets, whose aspect ratios (i.e. ratio of height to width of the structure) are high, two components of wind forces namely along-wind and acrosswind (vortex shedding phenomena) should be considered in the analysis. According to CICIND Model Code, there are procedures to calculate these two cited components of wind loads. However, TS498 and Eurocode 1 only deals with the along-wind loads. As the procedures of the cited standards are open to public, there is no need to define all of the symbols in the wind load calculations. One can obtain the details of the wind loading calculations in these studies [55-59]. Also, in these wind load calculations, basic wind speed is taken as $45 \mathrm{~m} / \mathrm{s}$. Although, the loads obtained from the standards are equivalent static loading which account for dynamic wind-structure interaction by "Gust Response Factor", the application of these loads to the masonry minaret is statically.

\subsection{Along wind loads according to TS498}

TS 498 only deals with the along-wind forces that the calculated along wind loads for the cited masonry minaret according to TS 498 are shown in Table 5.

\subsection{Wind loads according to CICIND Model Code}

CICIND Model Code not only deals with the along-wind forces but also deals with the across-wind forces caused from vortex shedding phenomena (vortex separated from the across-wind surface of minaret). The basic wind speed for the wind load calculation is determined as $45 \mathrm{~m} / \mathrm{s}$. The interference effects (vortex-induced motions) due to structures that are in close proximity to the representative minaret are not in the scope of this study.

\subsubsection{Along wind loads (CICIND Model Code)}

Along wind loads for the cited masonry minaret according to CICIND Model Code are shown in Table 6. In Table 6, only the important parameters in the calculation procedure are provided. In Table 6, $V(z)$ are denoting the average

Table 5 Wind load calculation according to TS 498

\begin{tabular}{lccccc}
\hline $\begin{array}{l}\text { Section } \\
\text { no }\end{array}$ & $\begin{array}{c}\text { Height from } \\
\text { ground }(\mathrm{m})\end{array}$ & $C_{f}$ & $\begin{array}{c}q \\
\left(\mathrm{kN} / \mathrm{m}^{2}\right)\end{array}$ & $\begin{array}{c}A \\
\left(\mathrm{~m}^{2}\right)\end{array}$ & $\begin{array}{c}W \\
(\mathrm{kN} / \mathrm{m})\end{array}$ \\
\hline 1 & $0-3.00$ & 1.60 & 0.50 & 6.60 & 1.76 \\
2 & $3.00-5.00$ & 1.60 & 0.50 & 3.70 & 1.48 \\
3 & $5.00-8.00$ & 1.60 & 0.50 & 4.50 & 1.20 \\
4 & $8.00-16.50$ & 1.60 & 0.80 & 12.75 & 1.92 \\
5 & $16.50-19.50$ & 1.60 & 0.80 & 3.78 & 1.61 \\
6 & $19.50-20.50$ & 1.60 & 0.80 & 0.63 & 0.81 \\
\hline
\end{tabular}


Table 6 Wind load calculation according to CICIND Model Code

\begin{tabular}{cccccccccccccc}
\hline & $\begin{array}{c}\text { Height from } \\
\text { ground }(\mathrm{m})\end{array}$ & $\begin{array}{c}V(z) \\
(\mathrm{m} / \mathrm{s})\end{array}$ & $C_{D}$ & $S$ & $E$ & $B$ & $i$ & $v T$ & $g$ & $G$ & $\begin{array}{c}w_{m} \\
(\mathrm{kN} / \mathrm{m})\end{array}$ & $\begin{array}{c}w_{g}(z) \\
(\mathrm{kN} / \mathrm{m})\end{array}$ & $\begin{array}{c}w(z) \\
(\mathrm{kN} / \mathrm{m})\end{array}$ \\
\hline 1 & $0-3.00$ & 38.02 & 0.662 & 0.482 & 0.0702 & 0.85 & 0.194 & 2737.967 & 4.124 & 3.759 & 4.389 & 0.019 & 4.408 \\
2 & $3.00-5.00$ & 40.84 & 0.662 & 0.482 & 0.0702 & 0.85 & 0.194 & 2737.967 & 4.124 & 3.759 & 6.387 & 0.192 & 6.579 \\
3 & $5.00-8.00$ & 43.62 & 0.662 & 0.482 & 0.0702 & 0.85 & 0.194 & 2737.967 & 4.124 & 3.759 & 3.938 & 0.323 & 4.261 \\
4 & $8.00-16.50$ & 48.27 & 0.662 & 0.482 & 0.0702 & 0.85 & 0.194 & 2737.967 & 4.124 & 3.759 & 1.702 & 0.432 & 2.135 \\
5 & $16.50-19.50$ & 49.41 & 0.662 & 0.482 & 0.0702 & 0.85 & 0.194 & 2737.967 & 4.124 & 3.759 & 4.246 & 5.041 & 9.286 \\
6 & $19.50-20.50$ & 49.76 & 0.662 & 0.482 & 0.0702 & 0.85 & 0.194 & 2737.967 & 4.124 & 3.759 & 6.458 & 8.909 & 15.367 \\
\hline
\end{tabular}

wind speed at level $z$ from the base; $C_{D}$, shape parameter; $S$, size reduction parameter; $E$, energy intensity spectrum; $B$, theoretical turbulence parameter; $i$, turbulence intensity; $v$, efficient oscillation ratio; $T$, modal period; $g$, maximum peak factor corresponding to height; $G$, instantaneous wind parameter. Also, total along-wind load on unit height is given at the last column of Table 6 that is the combination of mean wind load $\left(w_{m}\right)$ and wind load according to instantaneous wind effect $\left(w_{g}\right)$.

\subsubsection{Across-wind loads (CICIND Model Code)}

It is stated in CICIND Model Code that if the equation given in Eq. (5) is satisfied for all sections considered, there is no need to analyze the across-wind forces (formed from vortex separated from the across-wind surface of masonry minaret). In order to determine this requirement, the section above the height 19.50 meters is selected and analyzed whether Eq. (5) was satisfied or not.

For the section above the height of 19.50 meters, the weight of the minaret above this height is calculated as $G=9.01 \mathrm{kN}$. Also, the volume of the minaret for the height that the section considered, $V=17.24 \mathrm{~m}^{3}$.

$\frac{G}{V}=\frac{9.01 \mathrm{kN}}{17.24 \mathrm{~m}^{3}}=0.52 \mathrm{kN} / \mathrm{m}^{3}<2.0 \mathrm{kN} / \mathrm{m}^{3}$

From Eq. (15), it is evident that Eq. (5) is not satisfied that means across-wind actions on the masonry minaret of İskenderpaşa Mosque should be analyzed. The calculation of the peak base moment due to across-wind forces, $M_{\text {emax }}$, given with Eq. (6) is provided in Table 7.

\subsubsection{Combination of along wind base moments with the across wind base moments}

By using Eq. (7), the base moments obtained from along wind loads are combined with the moments obtained from across-wind loads that is provided in Table 7. Firstly, the along-wind moments at the base of the masonry minaret should be calculated. The along-wind moment at the base
Table 7 Across-wind peak base moment calculation

\begin{tabular}{lccccccc}
\hline $\begin{array}{l}\text { At 20,5 } \\
\text { Meters, } \\
\text { V(z20,5) }\end{array}$ & $S_{t}$ & $V_{c r}$ & $C_{L}$ & $\beta_{s}$ & $S_{p}$ & $\beta_{a}$ & $\begin{array}{c}M_{\text {emax }} \\
(\mathrm{kN} . \mathrm{m})\end{array}$ \\
\hline 35.12 & 0.21 & 7.57 & 0.15 & 0.04 & 0.12 & 0.000013 & -4.02 \\
\hline
\end{tabular}

of the cited masonry minaret due to mean along-wind load is calculated as M1 $(\mathrm{z})=1186.64 \mathrm{kN} . \mathrm{m}$. By this way, the combination of these two cited moments can be combined through Eq. (16).

$$
M_{w}(z)=\sqrt{(-4.02)^{2}+(1186.64)^{2}}=1186.65 \mathrm{kN} \cdot \mathrm{m}
$$

\subsection{Along wind loads according to Eurocode 1}

Buildings and civil engineering works with heights up to $200 \mathrm{~m}$ is in the scope of this standard. Total wind load is the combination of structural factor, the force coefficient, peak velocity pressure and the reference area for the structure considered. So many tables, formulas and figures in the wind load calculation procedure is provided for the users of the standard. Different from other standards, mean wind speed is not taken from a table or a chart as it is calculated from the basic wind velocity and the fundamental value of the basic wind velocity. Also the turbulence intensity is dealt in the calculation of peak velocity pressure.

Another difference used in this standard is the use of Reynolds number in the determination of force parameter. In Table 8, the calculated along wind loads for the cited masonry minaret according to Eurocode 1 are provided.

Table 8 Wind load calculation according to Eurocode 1

\begin{tabular}{lcccccc}
\hline $\begin{array}{l}\text { Section } \\
\text { no }\end{array}$ & $\begin{array}{c}\text { Height from } \\
\text { ground (m) }\end{array}$ & $c_{s} c_{d}$ & $C_{f}$ & $q_{p}(z)$ & $A_{r e f}$ & $\begin{array}{c}F_{w} \\
(\mathrm{kN} / \mathrm{m})\end{array}$ \\
\hline 1 & $0-3.00$ & 2.03 & 0.74 & $1,662.77$ & 6.60 & 5.49 \\
2 & $3.00-5.00$ & 2.03 & 0.74 & $2,756.84$ & 3.70 & 7.69 \\
3 & $5.00-8.00$ & 2.03 & 0.75 & $3,422.77$ & 4.50 & 7.79 \\
4 & $8.00-16.50$ & 2.03 & 0.75 & $4,670.76$ & 12.75 & 10.63 \\
5 & $16.50-19.50$ & 2.03 & 0.75 & $5,000.80$ & 3.78 & 9.61 \\
6 & $19.50-20.50$ & 2.03 & 0.77 & $5,102.86$ & 0.63 & 5.02 \\
\hline
\end{tabular}




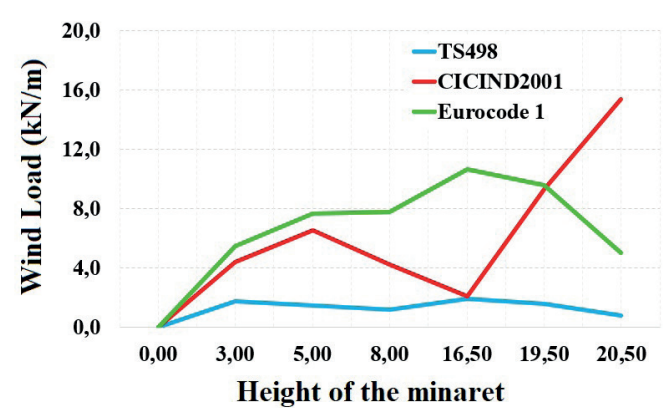

Fig. 15 Total along wind loads according to different standards

\subsection{Comparison of along-wind loads}

Total along wind loads $(\mathrm{kN} / \mathrm{m})$ obtained from TS498, CICIND Model Code and Eurocode 1 are shown in Fig. 15 along the height of the minaret. The interpretation of Fig. 15 is provided in the Discussion part of the study.

\section{Analysis results}

Seismic loads i.e. time histories of real earthquakes and design spectrums obtained from different standards for different soil types are separately applied to the FEM model of the minaret. Also, wind loads obtained from TS498, CICIND Model Code and Eurocode 1 are separately and statically applied as they include the dynamic effects in their formulations.

The dynamic response of the historical minaret of İskenderpaşa Mosque is investigated under two main categories namely top joint displacements and stress analyses.

The displacements at the top of the İskenderpaşa historical masonry minaret give an idea about the behavior of the minaret under dynamic seismic and wind loads. As indicated before, under severe winds or earthquakes, the vast majority of masonry or RC minarets survived or totally collapsed without showing any ductile behavior. Also, in order to determine the exact nonlinear behavior of the material, taking samples is not allowed from İskenderpaşa historical masonry minaret by the authorities. Therefore, the plastic behavior cannot be considered in this study. All of the calculations are in linear range that the details of the linear analyses are provided in the Methodology part of the study.

\subsection{Top displacements}

For masonry towers like masonry minarets, currently there is no document that provides the maximum allowable top deflection. However, from literature survey, some formulations are provided for the maximum allowable top deflection of such structures [15, 45]. According to Doğangün et al. [15], maximum relative displacement requirement of masonry structures can be calculated by using Eq. (17).
$\Delta_{\text {imax }} \leq \frac{0.02 \cdot h_{i}}{R}$

where $h_{i}$ and $R$ are the height of the structure and the behavior factor related to the ductility of structure, respectively. By utilizing Eq. (17), the maximum allowable top deflection of the considered masonry minaret is calculated as $0.14 \mathrm{~m}$.

The other equation provided by the ACI code [45] is shown in Eq. (18).

$Y_{\max }=3.33 \cdot h$,

where $Y_{\max }$ is denoting maximum lateral deflection in ( $\mathrm{mm}$ ) and $\mathrm{h}$ is denoting the chimney height in $\mathrm{m}$. Although this equation is provided for chimney structures, it can be applied to masonry minarets as they are both tall and slender structures. According to this equation, the maximum lateral deflection of the top of a chimney under all service conditions prior to the application of load factors shall not exceed the limits set forth by Eq. (18). By utilizing Eq. (18), the maximum allowable top deflection of the considered masonry minaret is also calculated as $0.07 \mathrm{~m}$. The maximum absolute displacement values obtained on top of the İskenderpaşa historical masonry minaret for the direction that the load applied are provided in Table 9.

The graphical representation of Table 9 is provided in Fig. 16.

From Fig. 16, it can be clearly seen that the top displacement value obtained from Kocaeli Earthquake is as close to the one obtained from wind loading of CICIND

Table 9 Maximum top displacements obtained from different loading types with reference limit values

\begin{tabular}{|c|c|c|c|c|}
\hline \multirow[b]{2}{*}{$\begin{array}{l}\text { Load } \\
\text { Type }\end{array}$} & \multirow[b]{2}{*}{$\begin{array}{c}\text { Name of the } \\
\text { Load }\end{array}$} & \multirow[b]{2}{*}{$\begin{array}{l}\text { Top displacement } \\
\qquad(\mathrm{cm})\end{array}$} & \multicolumn{2}{|c|}{ Limit Values } \\
\hline & & & $\begin{array}{l}\text { Doğangün et. } \\
\text { al [15] }(\mathrm{cm})\end{array}$ & $\begin{array}{l}\text { ACI [45] } \\
\quad(\mathrm{cm})\end{array}$ \\
\hline \multirow{3}{*}{ Wind } & TS498 & 8.72 & 14.00 & 7.00 \\
\hline & $\begin{array}{c}\text { CICIND } \\
\text { Model Code }\end{array}$ & 43.33 & & \\
\hline & Eurocode 1 & 22.94 & & \\
\hline & CICIND S1 & 23.45 & 14.00 & 7.00 \\
\hline & CICIND S2 & 31.26 & & \\
\hline & CICIND S3 & 39.06 & & \\
\hline & Eurocode A & 10.88 & & \\
\hline & Eurocode B & 14.27 & & \\
\hline & Eurocode C & 15.54 & & \\
\hline & $\begin{array}{c}\text { Kocaeli } \\
\text { Earthquake }\end{array}$ & 17.20 & 14.00 & 7.00 \\
\hline & $\begin{array}{c}\text { Düzce } \\
\text { Earthquake }\end{array}$ & 38.93 & & \\
\hline
\end{tabular}




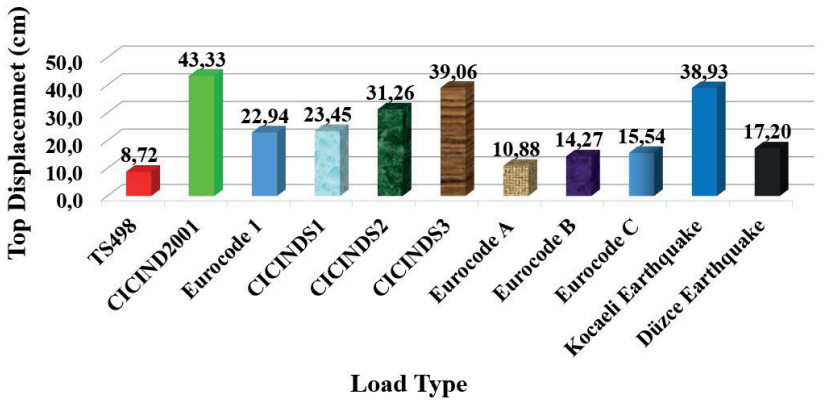

Fig. 16 Maximum top displacements according to different loads with reference limit values

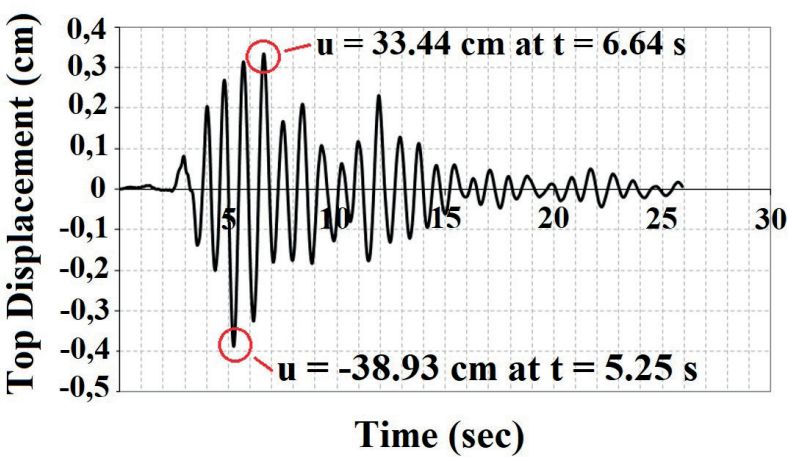

Fig. 17 Time histories of the top joint under Kocaeli Earthquake

Model Code. Because of this reason, the time history of the top displacement under Kocaeli Earthquake is provided in Fig. 17.

\subsection{Stress distributions}

From the preceding section, it is identified that the maximum top displacement response of the historical minaret of İskenderpaşa Mosque occurred under wind loading of CICIND Model Code. Therefore, in the stress distribution analyses, the stresses on the wall of the considered minaret occurred under this loading is evaluated. The maximum tensile $\left(S_{\max }\right)$, minimum compression $\left(S_{\min }\right)$ and shear stress distribution (in MPa) is provided in Figs. 18-20.

Moreover, as in the case of top displacement values, stresses obtained from Düzce Earthquake is as close to the one obtained from wind loading of CICIND Model Code. Because of this reason, the time histories of stresses obtained from Düzce Earthquake for the joining region of transition segment to the cylindrical body of the minaret are provided in Figs. 21-23.

The only thing that joins the masonry bricks is the mortar between the masonry bricks constituting the minaret. Therefore, the respective compressive and tensile stresses of the masonry material should be determined to compare the results of the dynamic analyses to the corresponding strength of the material. However, as stated before, it is

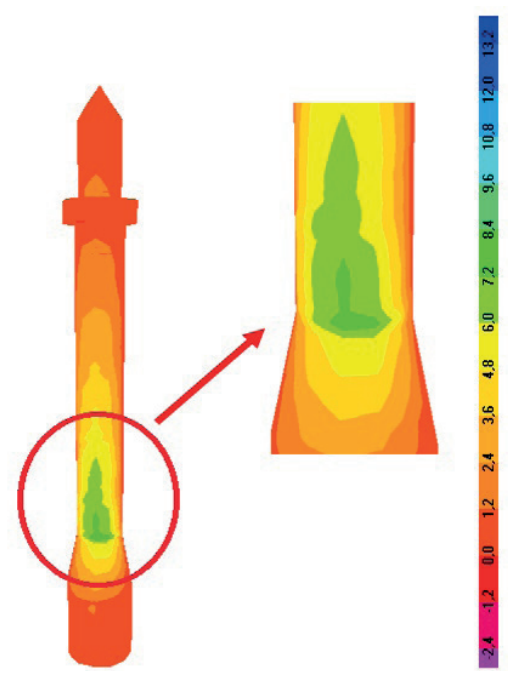

Fig. 18 Maximum tensile stress distribution over the considered minaret (in MPa)

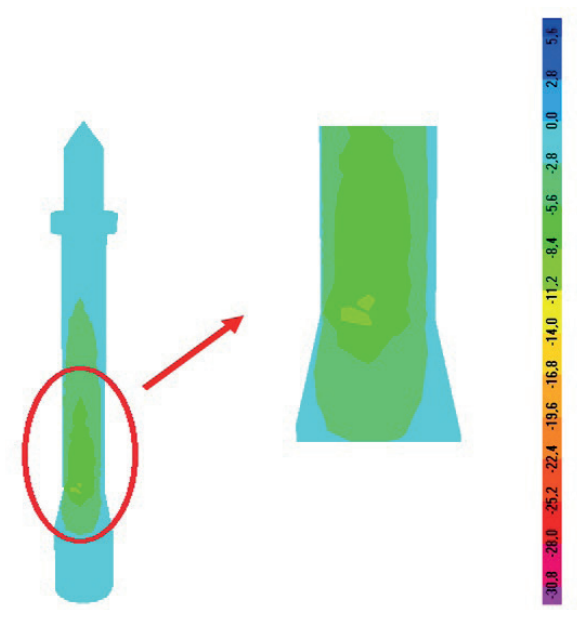

Fig. 19 Minimum compression stress distribution over the considered minaret (in $\mathrm{MPa}$ )

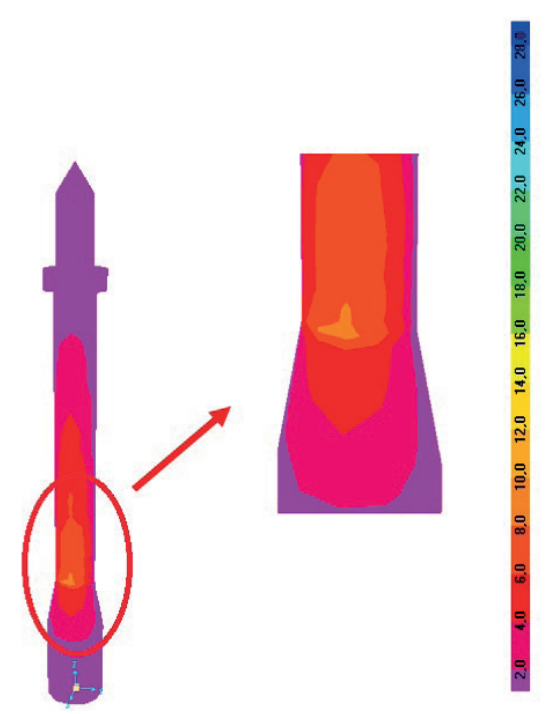

Fig. 20 Maximum shear stress distribution over the considered minaret (in MPa) 


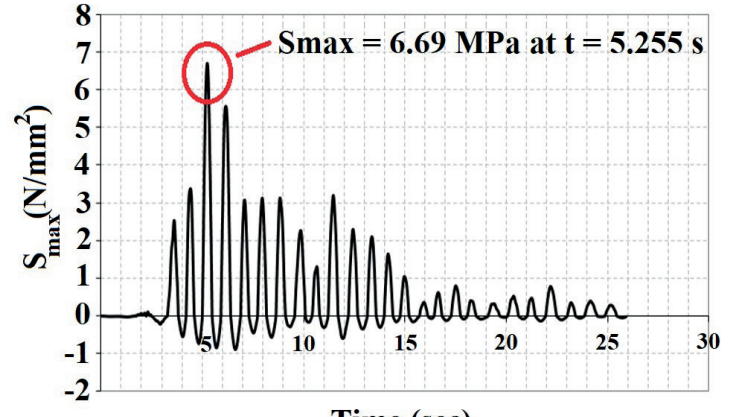

Time (sec)

Fig. 21 Time histories of the maximum stresses at the joining region of transition segment to the cylindrical body under Düzce Earthquake

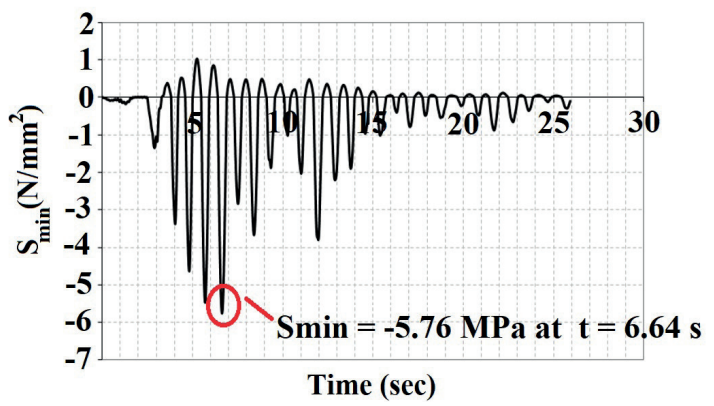

Fig. 22 Time histories of the minimum stresses at the joining region of transition segment to the cylindrical body under Düzce Earthquake

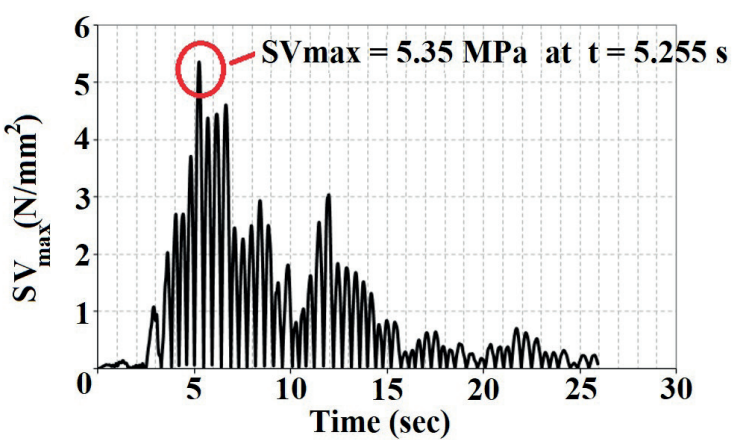

Fig. 23 Time histories of the maximum shear stresses at the joining region of transition segment to the cylindrical body under Düzce Earthquake

not allowed to take samples to determine the respective tensile and compressive strength of the masonry material. Because of this reason, the stress results obtained from dynamic analyses are compared with the reference limit values provided in the technical literature. In a study conducted by Doğangün et al. [15], the maximum compressive and tensile stresses for the limestone masonry commonly used in minaret construction in Turkey found to be 16.88 $\mathrm{MPa}$ and $0.9 \mathrm{MPa}$, respectively.

Also, in Table 10, the maximum and minimum tensile and compressive stress values (joining region of transition segment to the cylindrical body) obtained from
Table 10 Maximum stress values obtained from different loading types with reference limit values

\begin{tabular}{lcccc}
\hline & $\begin{array}{c}\text { Tensile } \\
(\mathrm{MPa})\end{array}$ & $\begin{array}{c}\text { Limit } \\
(\mathrm{MPa}) \\
(\text { Doğangün } \\
\text { et al. [15]) }\end{array}$ & $\begin{array}{c}\text { Compressive } \\
(\mathrm{MPa})\end{array}$ & $\begin{array}{c}\text { Limit } \\
(\mathrm{MPa}) \\
(\mathrm{Doğangün} \\
\text { et al. [15]) }\end{array}$ \\
\hline $\begin{array}{l}\text { CICIND } \\
\text { Model Code }\end{array}$ & 8.00 & 0.9 & 7.80 & 16.88 \\
$\begin{array}{l}\text { Düzce } \\
\text { Earthquake }\end{array}$ & 6.69 & 0.9 & 5.76 & 16.88 \\
\hline
\end{tabular}

different analyses are provided with the reference limit values in technical literature. CICIND Model Code and Düzce Earthquake is selected for the comparison due to the reason that absolute maximum values occurred under these loadings.

The graphical representation of Table 10 is provided in Fig. 24 and Fig. 25.

\section{Discussions and suggestions}

In this part of the study, the comments and discussions about the analysis results and some general suggestions are provided. This section is divided into four sections namely wind loads, top displacements, stresses and general suggestions.

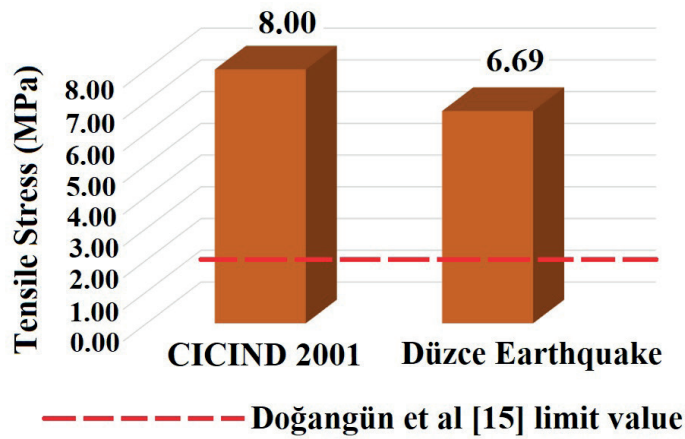

Fig. 24 Maximum tensile stress values according to different loads with reference limit values

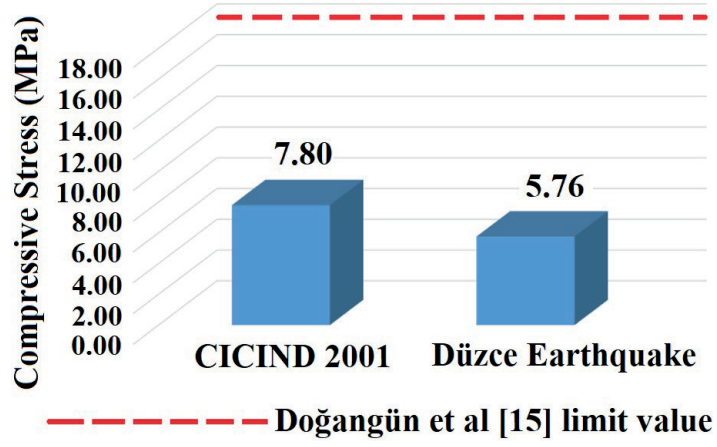

Fig. 25 Maximum compressive stress values according to different loads with reference limit values 


\subsection{Wind loads}

In this section, the interpretation of the wind loads calculated in Section 4 is performed. From Fig. 15, it is clearly seen that as the height of the minaret increases, the wind loads according to TS498 and Eurocode 1 have the trend to decrease. It is because of the reason that the wind load formulations of TS498 and Eurocode 1 includes the swept reference area by the wind. Moreover, it is evident that the reference area swept by the wind decreases as the height of the minaret increases. Also, except from the last section considered (between 19.50-20.50 meters), the wind loads obtained from Eurocode 1 are larger than the ones obtained from TS 498 and CICIND Model Code. CICIND Model Code includes the along and across-wind loading which may be the case for these types of tall and slender structures. This is because of the reason that the maximum analyses results are obtained under CICIND Model Code wind loading.

\subsection{Top displacements}

As it is clearly seen from Table 9 and Fig. 16 that the top displacements obtained from different methods are larger than the maximum allowable top deflection $(0.07 \mathrm{~m})$ provided from ACI [45]. Also, a few of the results obtained from different methods are lower than the maximum allowable top deflection $(0.14 \mathrm{~m})$ provided from Doğangün et al. [15]. Moreover, the maximum top displacement occurred under wind loading obtained from CICIND Model Code which $43.33 \mathrm{~cm}$. It should be stated that these displacement values occurred under linear assumption of the material and analyses. However, as stated before, this is not the case for the vast majority of masonry minarets collapsed at recent earthquakes that they did not behave linearly. However, as the exact nonlinear behavior of the material cannot be identified, it becomes a necessity to perform linear analysis instead of nonlinear static pushover analysis. Therefore, these values of displacements should not be evaluated as wrong. The vast majority of the masonry minarets survived or totally collapsed without showing any ductile behavior. Therefore, linear assumption of the material and analyses could not lead to uneconomical or unsafe design.

\subsection{Stress distributions}

It is clearly seen from Figs. 18-20 that the region that is shown in red circle is the place where maximum tensile and minimum compression stresses occurred. In addition to these, maximum shear stress occurred at the same region that is also given in red circle. This is the region where transition segment of the minaret combined or joined to the cylindrical body of the minaret. The dynamic behavior of this masonry minaret is primarily governed by flexure. Also, wind behavior is dominant in the structural behavior of Iskender Pasha historical minaret.

In recent severe earthquakes or windstorms given in the Introduction part of this study, so many masonry minarets were reported to be demolished or collapsed from the region just above the transition segment joining to the cylindrical body of the minaret. This is consistent with the stress aggregation shown in Figs. 18-20.

It is clear from Table 10 that the compression results obtained from dynamic analyses is lower than the ones provided from Doğangün et al. [15]. By this way, in compression, the limestone masonry bricks can be considered safe in stress point of view. However, as can be seen from Table 10 that the tensile stress of masonry is very low i.e. 0.9 MPa (provided from Doğangün et al. [15]) when compared with the ones obtained from dynamic analyses (approximately around 6 8 MPa). Therefore, this explains the mechanism of collapse of masonry minarets from the joining region where higher tensile stress (Fig. 18) accumulations occurred.

Moreover, like tensile and compression stresses, the maximum shear stresses (Fig. 20) also occurred at the transition segment of the minaret joined to the cylindrical body of the minaret.

\subsection{Suggestions}

At the end of the detailed technical literature search and the results of the analyses conducted in this study, some of the general suggestions are derived as follows:

- Technical regulations (in Turkey) about the detailed wind and seismic behavior of these type of masonry minarets and for the strengthening techniques should be formed in order to design more strong structures.

- Nonlinear static pushover analyses should be utilized for the approximate determination of the structural response of masonry minarets. However, as in the case of this study, if the structure has a historical heritage and nonlinear material properties cannot be determined, different linear analyses should be preferred for the wind and seismic behavior of the masonry minaret.

- As it is clear from the technical literature that no study dealt both the wind and seismic response of masonry minarets. However, as in the case of this 
study, wind behavior can become the dominant one among others. Therefore, both actions should be studied in the structural analyses.

- Across-wind loadings should be added and adapted to the technical regulations.

- In the future studies, the soil-structure interaction or the effect of other loading types such as blast-induced on the structural response should be investigated.

\section{Conclusions}

In this study, dynamic structural wind and earthquake response analyses of historical masonry minaret of İskenderpaşa Mosque is performed by using different method of analyses. These methods are TS498, CICIND Model Code and Eurocode 1 for the calculation of wind loads. Also, seismic actions are considered by using design spectrums (Eurocode 8 for soil types A, B ,C and CICIND Model Code for soil types S1, S2 and S3) and time histories of real ground motions (17 August 1999 Kocaeli and 12 November 1999 Düzce Earthquakes). The overall results derived from the findings of this study are summarized below.

- As stated in the introduction part of the study that from 1900 up to this time, so many destructive earthquakes and severe wind storms struck Turkey causing loss of lives and economy. Therefore, in order to save these types of historical structures, several precautions should be determined at the end of the structural analyses like performed in this study.

- The FEM (produced in SAP 2000) of the considered masonry minaret is updated by using the calibrated model given in the technical literature. By this modification, the error occurred in the dynamic parameters of the considered minaret decreased under $5 \%$. For example, for the first mode of the minaret, the natural frequency decreased from 1.19 to 1.11 by FEM modification. Also, the mode shapes of the FEM are checked and verified by using the calibrated model provided in the technical literature.

- The wind loading formulations of Eurocode 1 and TS498 includes the reference area swept by the wind. However, the formulation of wind loading according to CICIND Model Code do not include this reference area. Also, Eurocode 1 and CICIND Model Code utilize the dynamic parameters i.e. first mode natural frequency of the structure in the wind loading calculations. This is because of the reason of term "dynamic" used in the wind load calculations.
Also, different from other wind loading standards, CICIND Model Code deals with across-wind loads which can be counted as the challenging subject for wind engineers especially for tall and slender structures.

- The maximum top joint displacements obtained from the dynamic analyses showed that the maximum response occurred under wind loading of CICIND Model Code which is $43.33 \mathrm{~cm}$ among all other methods utilized. By this way it can be said that the dynamic behavior of this masonry minaret is wind dominant. Also, the order of the top displacements obtained from wind loadings for the considered masonry minaret is: TS498 < Eurocode $1<$ CICIND Model Code.

- According to top displacements, the displacement values increase from $\mathrm{S} 1$ to $\mathrm{S} 3$ type of soil for CICIND Model Code and A to C type of soil for Eurocode 8.

- The overall results of the dynamic analyses of the methods corresponding to top displacements are in this order: TS498 (Wind) < Eurocode A (Design) < Eurocode B (Design) $<$ Eurocode C (Design) $<$ Kocaeli Earthquake (Time History) $<$ Eurocode 1 (Wind) $<$ CICIND S1 (Design) < CICIND S2 (Design) < Düzce Earthquake (Time History) < CICIND S3 (Design) < CICIND Model Code (Wind).

- The comparison of the top displacements obtained from dynamic analyses with the one suggested from ACI [45] revealed that all of the top displacements from dynamic analyses are higher than the one suggested from the code. Also, a few of the top displacements obtained from dynamic analyses are under the value of the maximum allowable top displacement suggested from Doğangün et al. [15]. This shows that the masonry minaret can be considered unsafe from the top displacement point of view. Therefore, this masonry minaret should be strengthened to decrease top displacements and so to decrease the stress accumulations.

- The maximum, minimum and shear stresses accumulated at the region of joining of transition segment to the cylindrical body of the considered minaret. This explains the mechanism of collapse of the vast majority of masonry minarets in recent severe earthquakes or windstorms as higher tensile stress accumulations in this region cause separation of mortar between bricks. Therefore, the minaret collapses without showing any ductile behavior. 
- The compressive stresses obtained from dynamic analyses are in safe side when compared with the ones obtained from Doğangün et al. [15]. However, tensile stresses obtained from dynamic analyses are higher than the ones obtained from Doğangün et al. [15]. Also, the only thing that joins bricks together is the mortar between bricks. Therefore, tensile stresses create vital problem for dynamic seismic and wind response of masonry minarets.

Lastly, masonry minarets are historical heritage that should be preserved to the future generations. Therefore, the dynamic seismic and wind response of these tall and

\section{References}

[1] Warpinski, M. K., Connor, R. J., Hodgson, I. C. "Influence of Flexibility on the Fatigue Performance of the Base Plate Connection in High-Mast Lighting Towers", Journal of Structural Engineering, 136(3), pp. 324-329, 2010.

https://doi.org/10.1061/(ASCE)ST.1943-541X.114

[2] Jayalekshmi, B. R., Jisha, S. V., Shivashankar, R. "Analysis of Foundation of Tall R/C Chimney Incorporating Flexibility of Soil", Journal of the Institution of Engineers Series A, 98, pp. 211-217, 2017.

https://doi.org/10.1007/s40030-017-0218-y

[3] Elias, S., Matsagar, V., Datta, T. K. "Along-wind response control of chimneys with distributed multiple tuned mass dampers", Structural Control and Health Monitoring, 26(1), Article ID: e2275, 2018. https://doi.org/10.1002/stc.2275

[4] Erdogan, Y. S., Kocatürk, T., Demir, C. "Investigation of the Seismic Behavior of a Historical Masonry Minaret Considering the Interaction with Surrounding Structures", Journal of Earthquake Engineering, 23(1), pp. 112-140, 2019. https://doi.org/10.1080/13632469.2017.1309725

[5] AFAD, Turkey Earthquake Risk Map, [online] Available at: https:// deprem.afad.gov.tr/deprem-tehlike-haritasi?lang=en [Accessed: 20 January 2020]

[6] Doğangün, A., Tuluk, Ö. İ., Livaoğlu, R., Acar, R. "Traditional wooden buildings and their damages during earthquakes in Turkey", Engineering Failure Analysis, 13(6), pp. 981-996, 2006. https://doi.org/10.1016/j.engfailanal.2005.04.011

[7] AFAD "Destructive earthquakes occurred in Turkey" [online] Avalilable at: http://kyhdata.deprem.gov.tr/2K/kyhdata_ v4.php?dst=TU9EVUxFX05BTUU9ZWFydGhxdWFrZSZNT0RVTEVfVEFTSz1zZWFyY2g\%3D [Last accessed: 17.11.2019].

[8] Turkish State Meteorological Service "Turkey Wind Atlas", [online] Available at: https:/www.mgm.gov.tr/genel/ruzgar-atlasi.aspx [Accessed: 22 November 2019]

[9] HABERLER.COM "The Minaret of the 22-Year Mosque Was Destroyed" [online] Available at: https://www.haberler.com/22-yillik-caminin-minaresi-yikildi-haberi/ [Accessed: 22 August 2019 ] (in Turkish) slender structures should be identified in order to provide sufficient strengthening techniques. Although the results obtained in this study belong to one specific masonry minaret, the findings, observations and suggestions can be generally used or applied to many situations.

\section{Acknowledgments}

This study is dedicated to the venerable memory of my greatest teacher Prof. Dr. Ing. Ahmet DURMUŞ.

[10] HABERLER.COM "57-meter minaret destroyed in strong wind in Ordu" [online] Available at: https://www.haberler.com/ordu-da-57metrelik-minare-siddetli-ruzgarda-8074105-haberi/ [Accessed: 22 August 2019] (in Turkish)

[11] İhlas News Agency "The minaret of the historical mosque was destroyed in the earthquake" [online] Available at: https://www.iha. com.tr/haber-tarihi-caminin-minaresi-depremde-yikildi-659417/ [Accessed: 22 August 2019] (in Turkish)

[12] GazeteVan.com "Minaret Damaged In Earthquake In Erciş District Of Van Destroyed" [online] Available at: http://www.gazetevan. com/Van/57741-Vanin-Ercis-Ilcesinde-Depremde-Agir-Hasargoren-Minare-Yikildi.html [Accessed: 22 August 2019] (in Turkish)

[13] Doğangün, A., Acar, R., Livaoğlu, R., Tuluk, Ö. İ. "Performance of masonry minarets against earthquakes and winds in Turkey", presented at 1st International Conference on Restoration of Heritage Masonry Structures, Cairo, Egypt, April, 24-27, 2006.

[14] Doğangün, A., Sezen, H., Tuluk, Ö. İ., Livaoğlu, R., Acar, R. "Traditional Turkish Masonry Monumental Structures and their Earthquake Response", International Journal of Architectural Heritage, 1(3), pp. 251-271, 2007. https://doi.org/10.1080/15583050701436980

[15] Doğangün, A., Acar, R., Sezen, H., Livaoğlu, R. "Investigation of dynamic response of masonry minaret structures", Bulletin of Earthquake Engineering, 6, pp. 505-517, 2008. https://doi.org/10.1007/s10518-008-9066-5

[16] Altunişik, A. C. "Dynamic response of masonry minarets strengthened with fiber reinforced polymer (FRP) composites", Natural Hazards and Earth System Sciences, 11(7), pp. 2011-2019, 2011. https://doi.org/10.5194/nhess-11-2011-2011

[17] Atamturktur, S., Laman, J. A. "Finite element model correlation and calibration of historic masonry monuments", The Structural Design of Tall and Special Buildings, 21(2), pp. 96-113, 2012. https://doi.org/10.1002/tal.577

[18] Ural, A., Doğangün, A. "Crack development depending on bond design for masonry walls under shear", Structural Engineering and Mechanics, 44(2), pp. 257-266, 2012. https://doi.org/10.12989/sem.2012.44.2.257 
[19] Oliveira, C. S., Çaktı, E., Stengel, D., Branco, M. "Minaret behavior under earthquake loading: The case of historical Istanbul", Earthquake Engineering and Structural Dynamics, 41(1), pp. 19-39, 2011.

https://doi.org/10.1002/eqe.1115

[20] Dogangun, A., Sezen, H. "Seismic vulnerability and preservation of historical masonry monumental structures", Earthquake and Structures, 3(1), pp. 83-95, 2012. https://doi.org/10.12989/eas.2012.3.1.083

[21] Ural, A., Dogangun, A., Meraki, S. "Response evaluation of historical crooked minaret under wind and earthquake loadings", Wind and Structures, 17(3), pp. 345-359, 2013. https://doi.org/10.12989/was.2013.17.3.345

[22] Turk, A. M. "Seismic Response Analysis of Masonry Minaret and Possible Strengthening by Fiber Reinforced Cementitious Matrix (FRCM) Materials", Advances in Materials Science and Engineering, Article ID: 952497, 2013. http://dx.doi.org/10.1155/2013/952497

[23] Pekgökgöz, R. K., Gürel, M. A., Mammadov, Z., Çili, F. "Dynamic Analysis of Vertically Post-Tensioned Masonry Minarets", Journal of Earthquake Engineering, 17(4), pp. 560-589, 2013. https://doi.org/10.1080/13632469.2012.754734

[24] Abdel-Motaal, M. A. "Effect of piles on the seismic response of mosques minarets", Ain Shams Engineering Journal, 5(1), pp. $29-40,2014$. https://doi.org/10.1016/j.asej.2013.06.003

[25] Muvafik, M. "Field investigation and seismic analysis of a historical brick masonry minaret damaged during the Van Earthquakes in 2011", Earthquakes and Structures, 6(5), pp. 457-472, 2014 https://doi.org/10.12989/eas.2014.6.5.457

[26] Ural, A., Firat, F. K. "Evaluation of masonry minarets collapsed by a strong wind under uncertainty", Natural Hazards, 76, pp. 999$1018,2015$.

https://doi.org/10.1007/s11069-014-1531-7

[27] Cakir, F., Seker, B. S., Durmus, A., Dogangun, A., Uysal, H. "Seismic assessment of a historical masonry mosque by experimental tests and finite element analyses", KSCE Journal of Civil Engineering, 19, pp. 158-164, 2015. https://doi.org/10.1007/s12205-014-0468-4

[28] Hejazi, M., Moayedian, S. M., Daei, M. "Structural Analysis of Persian Historical Brick Masonry Minarets", Journal of Performance of Constructed Facilities, 30(2), 2015. https://doi.org/10.1061/(ASCE)CF.1943-5509.0000746

[29] Clemente, P., Saitta, F., Buffarini, G., Platania, L. "Stability and seismic analyses of leaning towers: the case of the minaret in Jam", The Structural Design of Tall and Special Buildings, 24(1), pp. $40-58,2015$. https://doi.org/10.1002/tal.1153

[30] Nohutcu, H., Demir, A., Ercan, E., Hokelekli, E., Altintas, G. "Investigation of a historic masonry structure by numerical and operational modal analyses", The Structural Design of Tall and Special Buildings, 24(13), pp. 821-834, 2015. https://doi.org/10.1002/tal.1213
[31] Basaran, H., Demir, A., Ercan, E., Nohutcu, H., Hokelekli, E., Kozanoglu, C. "Investigation of seismic safety of a masonry minaret using its dynamic characteristics", Earthquakes and Structures, 10(3), pp. 523-538, 2016.

https://doi.org/10.12989/eas.2016.10.3.523

[32] Kocaturk, T., Erdogan, Y. S. "Earthquake behavior of M1 minaret of historical Sultan Ahmed Mosque (blue mosque)", Structural Engineering and Mechanics, 59(3), pp. 539-558, 2016. https://doi.org/10.12989/sem.2016.59.3.539

[33] Demir, A., Nohutcu, H., Ercan, E., Hokelekli, E., Altintas, G. "Effect of model calibration on seismic behaviour of a historical mosque", Structural Engineering and Mechanics, 60(5), pp. 749-760, 2016. https://doi.org/10.12989/sem.2016.60.5.749

[34] Çaktı, E., Saygıl1, Ö., Lemos, J. V., Oliveira, C. S. "Discrete element modeling of a scaled masonry structure and its validation", Engineering Structures, 126, pp. 224-236, 2016. https://doi.org/10.1016/j.engstruct.2016.07.044

[35] Livaoğlu, R., Baștürk, M. H., Doğangün, A., Serhatoğlu, C. "Effect of geometric properties on dynamic behavior of historic masonry minaret", KSCE Journal of Civil Engineering, 20, pp. 2392-2402, 2016.

https://doi.org/10.1007/s12205-016-0622-2

[36] Erkal, A. "Transmission of Traffic-induced Vibrations on and around the Minaret of Little Hagia Sophia", International Journal of Architectural Heritage, 11(3), pp. 349-362, 2017. https://doi.org/10.1080/15583058.2016.1230657

[37] Nohutcu, H., Hokelekli, E., Ercan, E., Demir, A., Altintas, G. "Collapse mechanism estimation of a historical slender minaret", Structural Engineering and Mechanics, 64(5), pp. 653-660, 2017. https://doi.org/10.12989/sem.2017.64.5.653

[38] Hamdy, G. A., Kamal, O. A., El-Hariri, M. O. R., El-Salakawy, T. S. "Nonlinear analysis of contemporary and historic masonry vaulted elements externally strengthened by FRP", Structural Engineering and Mechanics, 65(5), pp. 611-619, 2018. https://doi.org/10.12989/sem.2018.65.5.611

[39] Erdil, B., Tapan, M., Akkaya, İ., Korkut, F. "Effects of Structural Parameters on Seismic Behaviour of Historical Masonry Minaret", Periodica Polytechnica Civil Engineering, 62(1), pp. 148-161, 2018. https://doi.org/10.3311/PPci.10687

[40] Nohutcu, H. "Seismic Failure Pattern Prediction in a Historical Masonry Minaret under Different Earthquakes", Advances in Civil Engineering, Article ID: 8752465, 2019. https://doi.org/10.1155/2019/8752465

[41] Serhatoğlu, C., Livaoğlu, R. "A fast and practical approximations for fundamental period of historical Ottoman minarets", Soil Dynamics and Earthquake Engineering, 120, pp. 320-331, 2019. https://doi.org/10.1016/j.soildyn.2019.02.010

[42] COMSOL "Multiphysics Cyclopedia" [online] Available at: https:// www.comsol.com/multiphysics/response-spectrum-analysis [Accessed: 22 November 2019].

[43] Turkish Standard Institute "TS 498: The calculation values of loads used in designing Structural elements", Ankara, Turkey, 1997. (in Turkish) 
[44] International Committee on Industrial Chimneys "CICIND Model Code for Concrete Chimneys, Part A: The Shell", 2nd ed., International Committee for Industrial Construction, Moers, Germany, 2001.

[45] American Concrete Institute "ACI 307/98 with commentary: Design and Construction of Reinforced Concrete Chimneys", American Concrete Institute, Farmington Hills, MI, USA, 1998.

[46] Comite Europeen De Normalisation "prEN 1991-1-4, Eurocode 1: Actions on Structures- General Actions- Part1-4: Wind Actions", Brussels, Belgium, 2004a.

[47] Comite Europeen De Normalisation "BS EN 1998-1 :2004, Eurocode 8: Design of structures for earthquake resistance - Part 1: General rules, seismic actions and rules for buildings", Brussels, Belgium, 2004b.

[48] Black Sea Cultural Inventory "İskenderpaşa Camii" [online] Available at: https://karadeniz.gov.tr/iskenderpasa-camii/ [Accessed: 22 August 2019] (in Turkish)

[49] Trabzon Provincial Directorate of Culture and Tourism "İskenderpaşa Mosque" [online] Available at: https://www.homeoftrabzon.com/sayfa/iskenderpasa-camii-19?d=en\&q [Accessed: 30 November 2019]

[50] Arslan, M. E., Durmus, A. "Modal parameter identification of infilled RC frames with low strength concrete using ambient vibration", Structural Engineering and Mechanics, 50(2), pp. 137-149, 2014.

https://doi.org/10.12989/sem.2014.50.2.137

[51] Cakir, F., Uysal, H. "Experimental modal analysis of brick masonry arches strengthened prepreg composites", Journal of Cultural Heritage, 16(3), pp. 284-292, 2015. https://doi.org/10.1016/j.culher.2014.06.003
[52] Computers \& Structures, Inc. "Sap 2000: Integrated Software for Structural Analysis and Design", [computer program] Available at: https://www.csiamerica.com/products/sap2000 [Accessed: 20 January 2020]

[53] CSI Knowledge Base "Solid" [online] Available at: https://wiki.csiamerica.com/display/kb/Solid [Accessed: 22 August 2019]

[54] Ahuja, A. K., Dalui, S. K., Ahuja, R., Gupta, V. K. "Effect of interference on the wind environment around high rise buildings", Journal of Wind Engineering \& Science, 2(1), pp. 1-8, 2005.

[55] Karaca, Z., Türkeli, E. "Determination and comparison of wind loads for industrial reinforced concrete chimneys", Structural Design of Tall and Special Buildings, 21(2), pp. 133-154, 2010. https://doi.org/10.1002/tal.617

[56] Karaca, Z., Turkeli, E. "The slenderness effect on wind response of industrial reinforced concrete chimneys", Wind and Structures, 18(3), pp. 281-294, 2014. https://doi.org/10.12989/was.2014.18.3.281

[57] Türkeli, E. "Determination and Comparison of Wind and Earthquake Responses of Reinforced Concrete Minarets", Arabian Journal for Science and Engineering, 39, pp. 3665-3680, 2014. https://doi.org/10.1007/s13369-014-0999-5

[58] Turkeli, E., Karaca, Z., Ozturk, H. T. "On the wind and earthquake response of reinforced concrete chimneys", Earthquakes and Structures, 12(5), pp. 559-567, 2017. https://doi.org/10.12989/eas.2017.12.5.559

[59] Türkeli, E. "The use of TS498 and TS-EN-1991-1-4 in the Wind Load Calculation of Reinforced Concrete Minarets Considering Soil-Structure Interaction", Journal of Natural and Applied Sciences, 23, pp. 84-93, 2019. https://doi.org/ 10.19113/sdufenbed.538551 